https://doi.org/10.15407/scine17.01.029

HEYETS, V., LUNINA, I., and STEPANOVA, $O$.

Institute for Economics and Forecasting, the NAS of Ukraine, 26, Panasa Myrnoho St., Kyiv, 01011, Ukraine,

+380 44280 1234, gvm@ief.org.ua

\title{
THE FORMATION OF FISCAL SPACE WHILE OVERCOMING VACCINE NATIONALISM AND ENSURING SUSTAINABILITY OF DEVELOPMENT
}

Introduction. The COVID-19 pandemic has caused the worst global economic and social crisis in recent decades. In such circumstances, the global community has been developing and taking measures to overcome the pandemic, one of which should be a rapid and unprecedented by scale vaccination of the population.

Problem Statement. Under conditions of intensive spread of the coronavirus infection, vaccination can halt it and become a factor of gradual economic recovery.

Purpose. Analysis of the preconditions and features of the development of fiscal space to ensure vaccination against COVID-19 in Ukraine, as one of the most important factors of this country's economic recovery in the current conditions of the global vaccine market.

Materials and Methods. Comparative analysis and theoretical generalization of developments and trends in the global market of vaccines against COVID-19 in current scholarly research and practical publications, as well as analysis of official statistics and analytical materials of the State Statistics Service of Ukraine, the United Nations, the World Health Organization.

Results. The authors have identified the current trends in the global market of vaccines against COVID-19, which have signs of fierce competition in conditions of insufficient production capacity and shortage of vaccines. The research has shown the contradictions between the emergence of the vaccine's status of a global public good and the vaccine nationalism. The authors have assessed the needs to expand Ukraine's fiscal space in order to carry out a successful vaccination of this country's population against COVID-19 in various alternative scenarios, with due consideration of the priorities of the coverage of particular population groups.

Conclusions. Creating a proper fiscal space for vaccination is one of the central elements of the fight against COVID-19. Such a vaccination would allow carrying out a gradual phased preventive immunization, breaking the chain of contagion, and attaining an economic recovery without repeated lockdowns.

Keywords: COVID-19 pandemic, vaccination, global public good, vaccine nationalism, fiscal space, and economic recovery.

Citation: Heyets, V., Lunina, I., and Stepanova, O. The Formation of Fiscal Space While Overcoming Vaccine Nationalism and Ensuring Sustainability of Development. Sci. innov. 2021. V. 17, no. 1. P. 29-41. https://doi.org/10.15407/scine17.01.029 
The COVID-19 pandemic has affected global society and, according to UN experts, is the largest humanitarian catastrophe in 75 years. Overcoming its consequences is associated with building a more stable and productive society and economy. As a result of the pandemic, the latter has suffered significant losses as a result of slowdown in its growth. The processes of transition to a new quality of the economy and society as a whole need innovations that are generated for these purposes and based on both sufficient and necessary conditions. At this stage, when the COVID-19 pandemic is gaining momentum, threatening the second and third waves, the key issue is to create the necessary framework for innovation that ensures the development and use of vaccines on a global scale. Below, there is a detailed description of how, under certain conditions, mass vaccination makes it possible to take control over the COVID-19 pandemic not only in an individual country, but also in throughout the world.

The purpose of this research is to analyze the preconditions and features of the development of the fiscal space to ensure vaccination against COVID-19 in Ukraine as one of the most important factors of economic recovery in the presentday conditions of the global vaccine market. Achieving this goal has necessitated addressing the following tasks: analysing the preconditions for the formation and development of the global market of vaccines against COVID-19 in presentday conditions; identifying the causes of contradictions between the processes of defining the vaccine against COVID-19 as a global public good and the emergence of vaccine nationalism; studying the conditions for expanding the fiscal space for vaccination of the population; identifying alternative scenarios for the priority of vaccination against COVID-19, and assessing the fiscal space based on the scenarios identified for Ukraine.

Mass vaccination against COVID-19 will change the course of the pandemic that has become a risk to the lives of people around the world and a trigger for the global economic crisis. Currently (as of December 2020), in 80 countries around the world, 237 COVID-19 vaccine candidates have been being developed, 154 of which have been being tried at the preclinical phase of research, 20 vaccines have been undergoing the first stage of research, 12 ones have been passing through the second stage, and 10 ones have been being tested at the third stage of research [2]. The development of COVID-19 vaccines that meet regulatory and licensing requirements is a long process that requires significant costs for the invention of drugs, the construction of laboratory facilities, the purchase of proper equipment and facilities, and the availability of $R \& D$ potential. The absence or lack of R\&D capacity and the need to finance significant costs prevent many countries from developing their own vaccine, in particular, force low- and middle-income countries to rely on R\&D of more powerful economies. At the same time, there are challenges in the supply of the vaccine to different countries of the world, caused by the unpreparedness of transport, logistics infrastructure and the "cold chain", as well as by the mismatch of production capacity with significant needs to quickly produce the required number of doses of COVID-19 vaccines.

Given this, the UN and the WHO have declared the need to give the SARS-CoV-2 vaccine the status of "global public good" [3]. China emphasizes that Chinese COVID-19 vaccines will be a global public good, thus China will contribute to the availability of vaccines for developing countries [4].

Upon the WHO initiative, a new international facility COVAX global cooperation within the ACT (the Access to COVID-19 Tools) has been established. It aims at accelerating the development, production, and equitable distribution of funds for diagnosis and treatment, and at providing $\mathrm{CO}$ VID-19 vaccines [5]. This initiative has been joined by 186 countries, which, according to WHO estimates, will enable forming a pool of vaccines in 2 billion doses and providing risk hedging in 


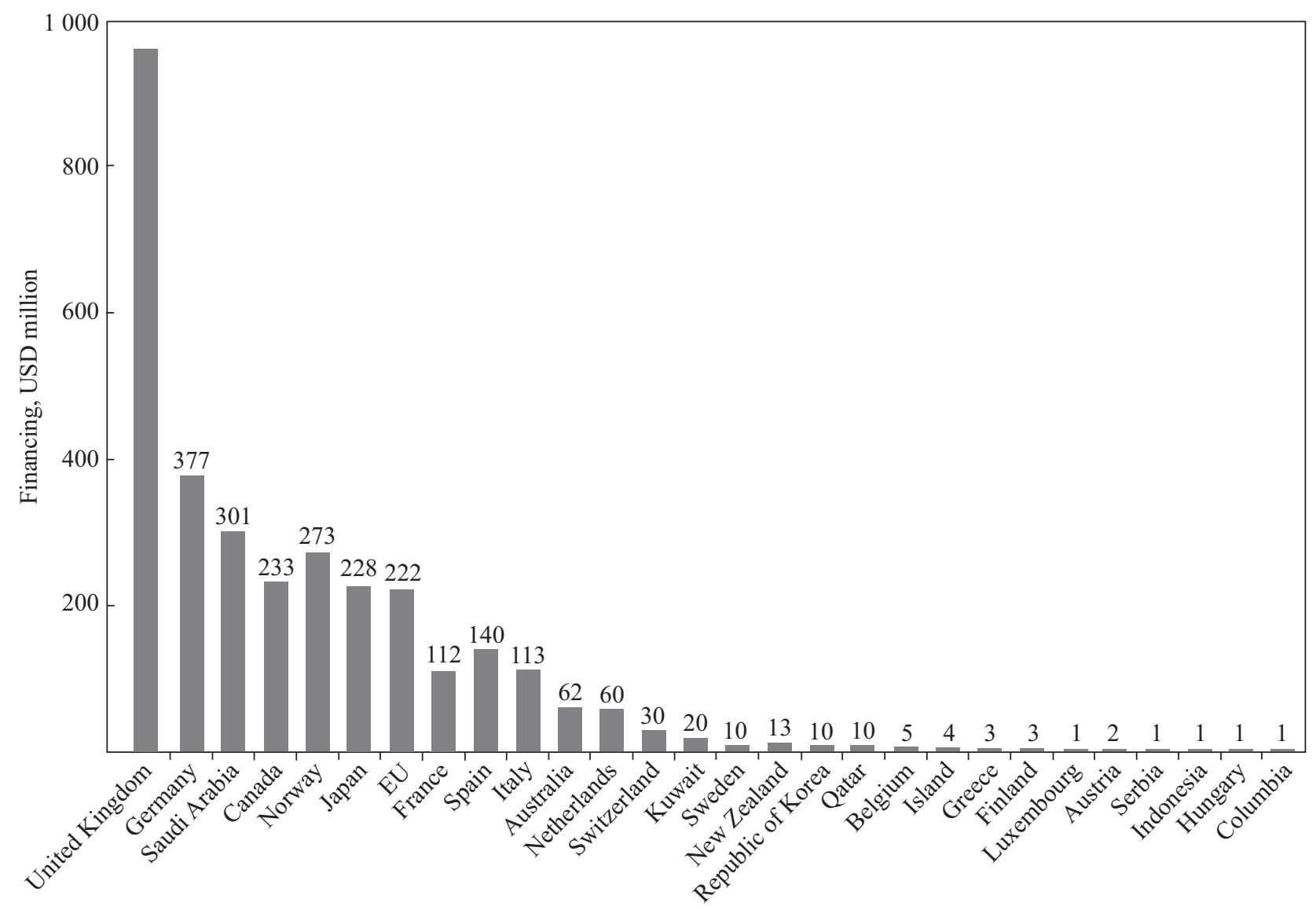

Fig. 1. Funding of COVAX facility by members countries (as of 16.11.2020), USD million Source: [9].

the case of problems with the effectiveness of vaccines of any type [6]. Such countries as the United States and the Russian Federation have not joined the global COVAX facility.

The vaccination process will begin with doses sufficient to immunize 3\% of the population having the highest risk, including health and social care workers. Vaccination will be expanded to cover $20 \%$ of the population of each country, starting with the groups most vulnerable to COVID-19 (the elderly and people with comorbidities) [7]. Ukraine has joined the COVAX global cooperation facility and expects to receive a free COVID-19 vaccine for immunization of $20 \%$ of the population [8].

ACT's budget, as of November 2020, reached USD 38 billion, out of which USD 3.59 billion was raised by donor countries for global COVAX cooperation activities. The largest donors were the United Kingdom, Germany, Saudi Arabia, and Canada (Fig. 1). The deficit of funding for ACT programs that have been already launched is USD 4.3 billion; the implementation of planned programs for 2021 requires additional funding of USD 23.9 billion [9]. In addition, to meet the immunization needs declared by COVAX member countries it us necessary to increase funding for already ordered doses of vaccines [10].

Despite the proclaimed global humanistic values and the outlined efforts of international organizations to implement them, in parallel, the there have been observed the processes that are now called "vaccine nationalism" [11] and "vaccine discrimination" [12]. J. Stiglitz notes that 
COVID-19 is not a "virus of equal opportunities" [13], as it disproportionately exacerbates inequality both within and between countries.

Initial production of COVID-19 vaccines will be insufficient to cover the majority of the world's population with immunization. According to some American researchers, taking into account the world's production capacity, the provision of the required amount of vaccine will take more than a year, and vaccination of the entire population may last until mid-2023 [14].

Under such conditions, some countries do not want to join the global facility of production and distribution of vaccines, considering it appropriate, above all, to meet the needs of the their own population. In addition, other countries participating in the global vaccine distribution facility are simultaneously trying to conclude separate bilateral contracts and compete for access to limited doses of vaccines and different manufacturers, which is also a sign of "vaccine nationalism".

According to the RAND" definition, "vaccine nationalism" is policies of countries prioritizing their own citizens and insisting on first access to vaccine supplies by entering into direct contracts with manufacturers and accumulating vaccine stocks and hoarding key components for its production, while discriminating against the population of other countries [15].

UN President A. Guterres warns of the challenges of "vaccine nationalism" for people around the world stating that COVID-19 does not recognize borders, if in today's interdependent global world there is at least one person who can get a coronavirus infection, no one in the world can feel safe [16]. WHO President T. Hebreyes emphasizes that vaccine nationalism will extend the pandemic rather than reduce it.

According to British analysts from Global Justice Now, the abandonment of global vaccine distribution facilities will lead to the lack of access

\footnotetext{
${ }^{1}$ RAND (Research and Development) is American noncommercial organization that acts as strategic research center and fulfills orders of the US government.
}

of most countries to the distribution of vaccines and their artificial shortage, which under the pandemic conditions would mean the spread of coronavirus disease and increased mortality [18]. According to the results of mathematical modeling of researchers from the United States [19], the spread of the COVID-19 pandemic kills more people if advanced economies buy up the vast majority of available vaccines than if these vaccines are distributed evenly through international facilities.

"Vaccine nationalism" may cause global economy losses estimated at USD $1.2-3.4$ trillion annually unless all countries adequately vaccinate the population [11]. That is, pre-vaccine economy conditions may emerge [20]. In these conditions, national economies will continue to decline, as full control over the spread of the virus worldwide will not be ensured because of vaccine shortages and immunization of individual populations only.

Despite these warnings, "vaccine nationalism" is likely to be inevitable. Thus, after the statement of Pfizer and BioNTech about the potential success of the COVID-19 vaccine [22], more than $80 \%$ of doses have been purchased by countries with a high economic development. Pfizer can produce this amount of vaccine (1.35 billion doses) as early as by the end of 2021, which enables vaccinating only $14 \%$ of the world's population [18]. The United States, Canada, the United Kingdom, and Japan have pre-ordered COVID-19 vaccines in amounts that exceed their population [23].

Competition in the development and production of COVID-19 vaccines is unprecedentedly high: in different countries, at different stages of development, there are hundreds of vaccine candidates. So, other manufacturers also have entered into preliminary contracts for vaccine supply (Fig. 2).

The largest market share of COVID-19 vaccine candidates (in terms of the number of contracts) belongs to AstraZeneca, due to the declared lowest cost (USD 5 per dose), as compared with other manufacturers [25]. AstraZeneca is an 


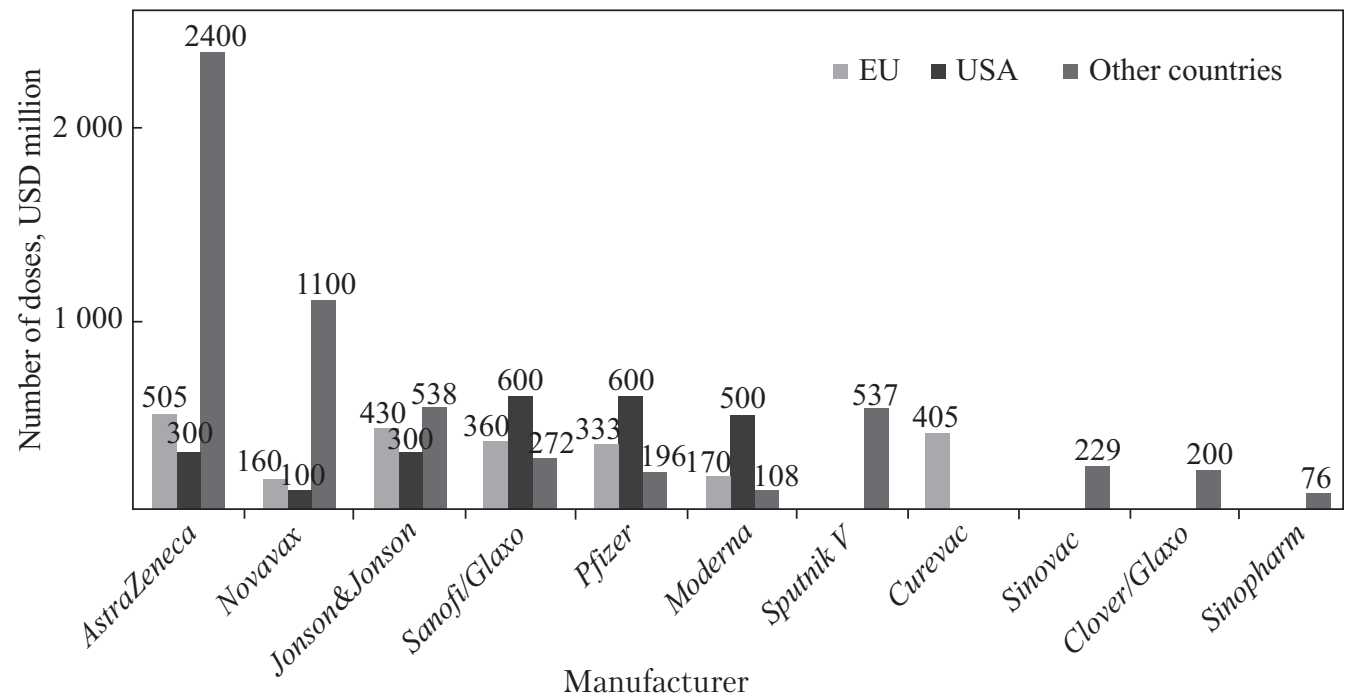

Fig. 2. Global market of contracts for COVID-19 vaccine supply, million doses Source: Bloomberg [24].

active member of the global COVAX facility, although currently it states that its vaccine is less effective than those of other competitors.

Important factors in the capture of the global COVID-19 vaccine market by various manufacturers include: vaccine efficacy; cost per dose; transportation and storage conditions, including temperature requirements; capacity of production facilities to provide the required number of vaccine doses; and how quick the manufacturer can launch a large-scale production and enter the markets of different countries.

Countries that are the first to be able to deploy mass vaccination will be able to move faster to rebuild their economies without re-lockdown [11]. WHO recommends that government organizations develop plans in advance for the procurement, supply, and distribution of vaccines, which should include the following measures [25]:

- The formation of demand for COVID-19 vaccine (includes conducting information campaigns to support vaccination by various groups of the population, development and adoption of legislation on compulsory vaccination);

- The planning of vaccination and vaccine distribution (between regions, medical institutions, etc.);
- The supply of vaccine;

- The monitoring of the coverage of the population with immunization from COVID-19.

The implementation of these measures requires the formation of a comprehensive facility for mass vaccination against COVID-19 and the identification of potential fiscal space, which is necessary to finance the relevant costs. While estimating such costs the following aspects shall be taken into consideration:

- the cost of vaccine purchase;

- the prioritization of vaccination of different groups of the population, given the potential risk of COVID-19 infection;

- the need to prepare logistics and transport networks for vaccination (given compliance with the "cold chain");

- the assessment of the need for vaccination equipment and its procurement;

- the formation of human resources for vaccination and training of medical staff;

- the assessment of the need for aid and materials for vaccination;

- the prior health screening and vaccination of different groups, the development of routes to vaccination sites, the formation of a new IT-system for monitoring the preparation, 
conduct, and results of vaccination, etc. [25, 27-30].

The United States has developed a system at the federal level to ensure that various segments of the population have access to the COVID-19 vaccine and that it is available free of charge. In particular, the Center for Medicare \& Medicaid Services has published a comprehensive plan to vaccinate people over the age of 65 and low-income people free of charge (any COVID-19 vaccine approved by the U.S. Food and Drug Administration, under federal-funded health insurance programs. Such a plan includes, among other things, measures to remove regulatory barriers to vaccination and guidelines for health care providers and insurance companies in different states to prepare the healthcare system for rapid vaccination. There have been done efforts to increase the number of medical establishments and other institutions (in particular, social security institutions, schools, etc.) having equipment that allows immunization [31]. The reimbursement for the cost of COVID-19 vaccination under the Medicare program will amount to USD 16.94 for the first dose and USD 28.39 for the second one, i.e. the total cost is USD 45.33.

In 2019, the share of the U.S. population covered by federal health insurance plans accounted for $26.2 \%$, while $63.7 \%$ of the population was involved in private health insurance programs [32]. Given this fact, according to the requirements of the U.S. Department of Labor, the private health insurance programs will be forced to cover the cost of the COVID-19 vaccine without additional costs to the population [33]. For immunization of the uninsured population (in 2019, it numbered 32.8 million people), the medical institutions may receive a reimbursement from the Fund for Assistance to Medical Service Providers [31].

Since the global race of COVID-19 vaccine developers seems to come to end, transnational and national transport and logistics companies have been developing plans to form vaccine supply chains, including transportation and storage, from the manufacturer to the health facility. In the United States, transportation plans also cover large pharmaceutical distribution networks.

The International Air Transport Association has estimated that it takes two years to transport the vaccine by plane (delivery of 14 billion doses of COVID-19 vaccine by a Boeing 747 cargo liner) [34]. In addition, there is a need to prepare logistics centers, in particular, deep-frozen sites for storage of the vaccine and its further distribution. For these purposes, United Parcel Service Inc. has been built appropriate logistics centers in the United States and the Netherlands [35]. As reported by the International Air Transport Association, successful attempts are being made to transport the COVID-19 vaccine by plane for research, and several airlines have declared their readiness to transport the vaccines. Thus, Deutsche Lufthansa AG has prepared equipment, in particular, re-equipped aircraft, and warehouses for rapid transportation of COVID-19 vaccines [36]. Thus, the formation of a modern network of transportation and storage of the vaccine is a very complicated task for developing countries and least developed countries, as its implementation requires significant financial resources.

In Ukraine, for the vaccination against COVID-19, the draft Law of Ukraine on the National Budget of Ukraine for 2021 provides appropriate funding totaling UAH 2.6 billion [37] The budget request of the Ministry of Healthcare of Ukraine estimates the number of vaccines from acute respiratory disease COVID-19 caused by coronavirus SARS-CoV-2 to be purchased for vaccination of at-risk groups in 2021 at 4,333,333 units, and the average cost of one vaccine is UAH 600 [38]. In this case, the level of vaccine supply to the population of Ukraine, which belongs to the at-risk groups, is $100 \%$.

Ukraine is currently suffering from intensive circulation of infectious disease caused by coronavirus SARS-CoV-2 [39]. Given that, the availability of sufficient financial resources is a key factor for ensuring the effectiveness of COVID-19 vaccination [40]. Successful vaccination in Ukraine requires the assessment of the potential fiscal 
space needed to implement alternative COVID-19 vaccination scenarios. The generalization of the best approaches of different countries and WHO recommendations to vaccination allows identifying the following alternative scenarios for the formation of fiscal space in Ukraine:

- The fiscal space for funding vaccination against COVID-19 in order to form an immune layer (according to the WHO definition);

- The fiscal space for finding vaccination against COVID-19 in accordance with COVAX recommendations (given the phases and stages of prioritization of population coverage);

- The fiscal space for funding vaccination against COVID-19 of certain groups of the population with the highest risk of being infected.

According to WHO experts, in order to ensure that vaccination against COVID-19 breaks the chain of infection, it shall be mass, with immunization covering $60-70 \%$ of the population, to form an immune layer [26]. Given the above, for the first scenario, the sufficient fiscal space required for vaccination of $70 \%$ of the population has been estimated.

The results of the estimates given in Table 1 indicate that in Ukraine, there is a need to raise a significant amount of fiscal space. The minimum amount of fiscal space of UAH 8.26 billion corresponds to vaccinating the population of Ukraine from COVID-19 for the formation of the immune layer with the use of vaccine manufactured by AstraZeneca, because of the lowest cost of two doses of vaccine. The largest amount of fiscal space (UAH 119.63 billion) is necessary for immunizing the population with COVID-19 vaccine from the Chinese manufacturer Sinopharm.

The estimate results justify the need for additional funding of vaccination for the formation of immune layer, as compared with the funds budgeted in the draft Law of Ukraine on the National Budget for 2021. These results need considerable attention, as the amount of fiscal space required for vaccination and the formation of immune layer in Ukraine is very significant and may range from $5.19 \%$ to $75.15 \%$ of the total annual expenditure of the consolidated budget of Ukraine (2021) for healthcare.

For to the second proposed scenario, the fiscal space for funding vaccination from COVID-19 has been estimated based on the COVAX recommendations (Table 2), given the prioritization.

Table 1. Fiscal Space Necessary for Vaccinating Ukraine's Population from COVID-19 to Form the Immune Layer, UAH billion

\begin{tabular}{|l|c|c|c|c|}
\hline \multicolumn{1}{|c|}{$\begin{array}{c}\text { COVID-19 vaccine } \\
\text { manufacturers }\end{array}$} & $\begin{array}{c}\text { Estimated cost } \\
\text { of COVID-19 } \\
\text { vaccine } \\
\text { (2 doses), } \\
\text { USD }\end{array}$ & $\begin{array}{c}\text { Funds required for } \\
\text { vaccinating Ukraine's } \\
\text { population from } \\
\text { COVID-19 (formation } \\
\text { of the immune layer), } \\
\text { UAH billion }\end{array}$ & $\begin{array}{c}\text { The need for additional } \\
\text { funding of vaccination } \\
\text { to form an immune layer, } \\
\text { as compared with the funds } \\
\text { budgeted for 2021, } \\
\text { UAH billion }\end{array}$ & $\begin{array}{c}\text { Share of funds required for } \\
\text { vaccination from COVID-19 } \\
\text { in the planned expenditure } \\
\text { of the consolidated budget } \\
\text { of Ukraine for healthcare } \\
\text { for 2021, \% }\end{array}$ \\
\hline Moderna 1* & 50.00 & 41.31 & 38.71 & 25.95 \\
Moderna 2 & 74.00 & 61.13 & 58.53 & 38.40 \\
Gamalia NRDCEM [42] & 20.00 & 16.52 & 13.92 & 10.38 \\
Pfizer Ta BioNTech [43] & 39.00 & 32.22 & 29.62 & 20.24 \\
Johnson E Johnson [44, 45] & 20.00 & 16.52 & 13.92 & 10.38 \\
AstraZeneca [46] & 10.00 & 8.26 & 5.66 & 3.19 \\
Sinovac Biotech [47] & 59.50 & 49.16 & 46.56 & 75.15 \\
Sinopharm [48] & 144.80 & 119.63 & 117.03 & 30.88 \\
\hline
\end{tabular}

Note. ${ }^{*}$ For Moderna, two price options are considered, depending on the size of ordered batch, according to the announced information. Details remain undisclosed [41].

Source: Prepared by the authors. 
Heyets, V., Lunina, l., and Stepanova, 0.

Table 2. COVAX Global Facility for COVID -19 Vaccine Distribution and Road Map for Prioritization of Vaccinating Different Groups of Population

\begin{tabular}{|c|l|l|l|}
\hline \multicolumn{2}{|c|}{ COVAX global facility } & \multicolumn{2}{c|}{ Road Map of Prioritization } \\
\hline \multicolumn{1}{|c|}{ Phases } & $\begin{array}{c}\text { \% of Ukraine's population } \\
\text { to be vaccinated }\end{array}$ & $\begin{array}{l}\text { Vaccination } \\
\text { stage }\end{array}$ & $\begin{array}{l}\% \text { of Ukraine's population } \\
\text { to be vaccinated }\end{array}$ \\
\hline $\begin{array}{l}\text { Phase 1. Proportional distribution to cover the first } \\
\text { priority target groups of the population }\end{array}$ & $\begin{array}{l}\text { Indicative first tranche: pro- } \\
\text { vision with vaccines 3\% } \\
\text { Further supplies: provision } \\
\text { of up to 20\% of population } \\
\text { with vaccines } \\
>20 \%\end{array}$ & Stage I & $1-10 \%$ \\
$\begin{array}{l}\text { Phase 2. Balanced distribution of vaccination bet- II } \\
\text { ween different groups, which should be based on the } \\
\text { assessment of risk of being infected with COVID-19 }\end{array}$ & $\begin{array}{l}\text { Stage III } \\
\text { Stage IV }\end{array}$ & $\begin{array}{l}21-50 \% \\
>50 \%\end{array}$ \\
\hline
\end{tabular}

Source: [49].

Given these indicators for vaccination of the population at the appropriate stages, the fiscal space required for vaccinating Ukraine's population from COVID-19 has been estimated for alternative phases and stages, taking into account differences in the cost of vaccines selected for the study (Table 3).

The largest fiscal space shall be formed for population vaccination at the final, IV stage, which will require from UAH 6.02 to UAH 87.16 billion, and the smallest one shall be raised at the first stage, for which it is necessary from UAH 0.35 billion to UAH 5.13 billion, depending on the choice of the vaccine manufacturer.

The WHO has proposed the detailed Roadmap for prioritizing population groups for vaccines against COVID-19 [30], which provides for early vaccination of $3 \%$ of the population, including health workers. The second stage of vaccination should cover $17 \%$ of the population, especially the elderly and groups with comorbidities. At the third stage of vaccination, it is advisable to vaccinate up to $50 \%$ of the population, including education sector, police, armed forces, food industry, agriculture, government and municipal officials whose job is necessary for the critical operation of the infrastructure. At this stage, according to WHO recommendations, it is also advisable to cover social/employment groups unable to social distance (examples: detention facilities, dormitories, low in- come persons in dense urban neighbourhoods, homeless people and those living in informal settlements or urban slums, etc.) At the last stage, it is proposed to immunize the population not covered at the previous stages [49]. This composition of social groups for vaccination of the population is provided in the conditions of intensive circulation of infectious disease caused by coronavirus SARS$\mathrm{CoV}-2$. In the vase of changes in the pandemic situation, it is advisable to re-prioritize the vaccination.

According to the recommendations of international organizations, each country may apply different approaches to the formation of plans for vaccination of the population, taking into account the socio-demographic structure and the structure of employment [49]. In this research the fiscal space for vaccination against COVID19 in Ukraine has been estimated for different options of prioritization of social groups (Table 4):

- Health workers and social security system;

- Health workers, social security and education sectors;

- Adults groups (over 60 years).

Thus, health workers and social security sector are undoubtedly exposed to a very high risk of being infected and transmitting the SARS-CoV-2 virus in the epidemiological scenario of intensive circulation of infection among the population. According to the State Statistics Service of Ukraine, in Ukraine, people employed in the field of 
healthcare and social security total 974.2 thousand or $2.34 \%$ of the total population [50]. Their vaccination, according to the author's estimates, requires the formation of a fiscal space from UAH 0.28 to UAH 3.99 billion.

The highest level of priority of vaccination of health workers is explained by the following factors. Health professionals work in conditions of constant high risk of infection, possible disease, and death. In addition, there is a risk of further transmission of the infection to individuals at a high risk in terms of adverse effects of COVID-19. Ensuring the protection of health workers will keep vital health services available to respond to the COVID-19 pandemic.

In order to reduce mortality and morbidity from COVID-19, the population of older age groups, who usually have severe comorbidities and therefore are at a significant risk of severe morbidity and mortality, also is prioritized for vaccination [49]. At the beginning of 2020, in Ukraine, the older age groups (over 60 years) counted 9978.19 thousand [51], i.e. $23.9 \%$ of the population. Vaccination of these groups requires a fiscal space from UAH 2.82 to UAH 40.89 billion, depending on the selected vaccine manufacturer.

It should be noted that these estimates include only the cost of the COVID-19 vaccine. However, vaccination against COVID-19 also requires funding for other costs [52-54]: the cost of med-
Table 3. Fiscal Space Required for Vaccinating Ukraine's Population against COVID-19 for Alternative Options, by Phases and Stages, UAH billion

\begin{tabular}{|l|c|r|r|c|}
\hline \multirow{2}{*}{$\begin{array}{c}\text { COVID-19 vaccine } \\
\text { manufacturers }\end{array}$} & \multicolumn{2}{|c|}{ Phase 1 } & \multicolumn{2}{c|}{ Phase 2 } \\
\cline { 2 - 5 } & Stage I & Stage II & Stage III & Stage IV \\
\hline Moderna 1 & 1.77 & 10.03 & 17.11 & 30.10 \\
Moderna 2 & 2.62 & 14.85 & 26.20 & 44.54 \\
Gamalia NRDCEM & 0.71 & 4.01 & 7.08 & 12.04 \\
Pfizer Ta BioNTech & 1.38 & 7.82 & 13.81 & 23.47 \\
Johnson \& Johnson & 0.71 & 4.01 & 7.08 & 12.04 \\
AstraZeneca & 0.35 & 2.01 & 3.54 & 6.02 \\
Sinovac Biotech & 2.11 & 11.94 & 21.07 & 35.81 \\
Sinopharm & 5.13 & 29.05 & 51.27 & 87.16 \\
\hline
\end{tabular}

Source: Prepared by the authors.

ical staff, the cost of additional materials (such as injection syringes), the cost of safe containers, vaccine transportation and storage costs (with sufficient cold chain capacities4, including pulse power and continuous maintenance facilities), training and education of personnel, other indirect costs (electricity, water supply and drainage, heating, etc.).

Hence, the results of the assessment of the potential amount of fiscal space that should be raised in Ukraine for vaccination of the population against COVID-19, have proven that the budget funds provided for such measures in 2021 are insufficient, and for effective immunization of

Table 4. Fiscal Space Required for Vaccinating the Priority Social Groups at High Risk of Being Infected with COVID-19, UAH billion

\begin{tabular}{|l|c|c|c|}
\hline $\begin{array}{c}\text { COVID-19 vaccine } \\
\text { manufacturers }\end{array}$ & $\begin{array}{c}\text { Funds required for vaccination } \\
\text { of health workers and social security } \\
\text { sector, UAH billion }\end{array}$ & $\begin{array}{c}\text { Funds required for vaccination } \\
\text { of health workers, social security } \\
\text { and education sectors, UAH billion }\end{array}$ & $\begin{array}{c}\text { Funds required for vaccination } \\
\text { of adults groups (60+), } \\
\text { UAH billion }\end{array}$ \\
\hline Moderna 1 & 1.38 & 3.34 & 14.12 \\
Moderna 2 & 2.04 & 4.95 & 20.90 \\
Gamalia NRDCEM & 0.55 & 1.34 & 5.65 \\
Pfizer Ta BioNTech & 1.08 & 2.61 & 11.01 \\
Johnson \&Johnson & 0.55 & 1.34 & 5.65 \\
AstraZeneca & 0.28 & 0.67 & 2.82 \\
Sinovac Biotech & 1.64 & 3.98 & 16.80 \\
Sinopharm & 3.99 & 9.68 & 40.89 \\
\hline
\end{tabular}

Source: prepared by the authors. 
the population it is necessary to find additional sources of funding. Today, many countries around the world have been rapidly making thorough extremely complex preparations for vaccination against COVID-19 on an unprecedented scale in the face of fierce global competition for access to the vaccine. The formation of a fiscal space for vaccination of the population against COVID-19 is a key component of such preparations in order to ensure:
- Gradual preventive immunization of the population in order to break the infection chain; - Reduction in morbidity and mortality rates;

- Reduction in the burden on the healthcare system;

- Reduction in potential future costs for economic development and, accordingly, for the state and local budgets of the country, as well as faster transition to economic recovery without the re-introduction of lockdowns.

\section{REFERENCES}

1. Amid Threat of Catastrophic Global Famine, COVID-19 Response Must Prioritize Food Security, Humanitarian Needs. UN General Assembly. Thirty-first special session, 2nd meeting (resumed). URL: https://www.un.org/press/en/2020/ ga12294.doc.htm (Last accessed: 06.12.2020).

2. The COVID-19 vaccine race. URL: https://www.gavi.org/vaccineswork/covid-19-vaccine-race (Last accessed: 01.12.2020).

3. Global action to combat coronavirus: the first meeting of the Coordinating Council of the Initiative to Accelerate Access to COVID-19 Controls. URL: https://www.who.int/ru/news/item/10-09-2020-coronavirus-global-response-accessto-covid-19-tools-accelerator-facilitation-council-holds-inaugural-meeting [in Russian] (Last accessed: 20.11.2020).

4. China is developing vaccines against COVID-19 as a global public good. URL: http://russian.people.com.cn/n3/2020/ 0911/c95181-9759233.html [in Russian] (Last accessed: 12.10.2020).

5. The Access to COVID-19 Tools (ACT) Accelerator. URL: https://www.who.int/initiatives/act-accelerator (Last accessed: 27.10.2020).

6. Why we need a "portfolio approach" to COVID-19 vaccine development. URL: https://www.gavi.org/vaccineswork/ why-we-need-portfolio-approach-covid-19-vaccine-development (Last accessed: 12.11.2020).

7. WHO SAGE values framework for the allocation and prioritization of COVID-19 vaccination. URL: https://apps. who.int/iris/bitstream/handle/10665/334299/WHO-2019-nCoV-SAGE_Framework-Allocation_and_prioritization2020.1-eng.pdf?sequence $=1 \&$ isAllowed $=y$ (Last accessed: 20.11 .2020 ).

8. COVAX: Ukraine may receive 8.5 million doses of COVID vaccine. URL: https://www.ukrinform.ru/rubric-society/ 3134628-covax-ukraina-mozet-polucit-85-milliona-doz-covidvakciny.html (Last accessed: 15.11.2020).

9. Access to COVID-19 tools funding commitment tracker. URL: https://www.who.int/publications/m/item/access-tocovid-19-tools-tracker (Last accessed: 05.12.2020).

10. These are the countries that have pre-ordered the most COVID vaccines.URL: https://www.weforum.org/agenda/ 2020/11/countries-vaccines-covid-coronavirus-pandemic-moderna-pfizer-astrazeneca-covax-who?utm_source $=$ twitter\&utm_medium=social_scheduler\&utm_term=COVID-19\&utm_content $=27 / 11 / 2020+14: 00$ (Last accessed: 27.11.12).

11. Hafner M., Yerushalmi E. COVID-19 and the cost of vaccine nationalism. RAND Corporation.2020. URL: https://www. rand.org/content/dam/rand/pubs/research_reports/RRA700/RRA769-1/RAND_RRA769-1.pdf (Last accessed: 20.11.2020).

12. Ghosh J. Vaccine Apartheid. URL: https://www.project-syndicate.org/commentary/pfizer-vaccine-doses-claimed-byrich-countries-weakens-covax-by-jayati-ghosh-2020-11 (Last accessed: 20.11.2020).

13. Stiglitz J. Conquering the Great Divide. Finance \& Development. September 2020. IMF. URL: https://www.imf.org/ external/pubs/ft/fandd/2020/09/COVID19-and-global-inequality-joseph-stiglitz.htm (Last accessed: 15.11.2020).

14. Mc Donnell A COVID-19 Vaccine Predictions: Using Mathematical Modelling and Expert Opinions to Estimate Timelines and Probabilities of Success of COVID-19 Vaccines. Washington (DC): Center for Global Development. URL: https://www.cgdev.org/sites/default/files/COVID-19-Vaccine-Predictions-Full.pdf (Last accessed: 24.10.2020).

15. Hafner M. The global economic cost of COVID-19 vaccine nationalism. URL:https://www.rand.org/pubs/research briefs/RBA769-1.html (Last accessed: 28.11.2020).

16. A tender has been announced for 2 billion doses of COVID-19 vaccine. UN. Healthcare. 2020. URL: https://news. un.org/ru/story/2020/11/1390402 [in Russian] (Last accessed: 14.11.2020).

17. WHO chief warns against COVID-19 'vaccine nationalism' URL: https://news.cgtn.com/news/2020-10-26/WHOchief-warns-against-COVID-19-vaccine-nationalism--UTD8hxtXeE/index.html (Last accessed: 28.10.2020). 
18. Most of Pfizer's vaccine already promised to richest, campaigners warn. URL: https://www.globaljustice.org.uk/news/ 2020/nov/11/most-pfizers-vaccine-already-promised-richest-campaigners-warn (Last accessed: 15.11.2020).

19. Chinazzi, M., Davis, J. Estimating the effect of cooperative versus uncooperative strategies of COVID-19 vaccine allocation: a modeling study. URL: https://www.mobs-lab.org/uploads/6/7/8/7/6787877/global_vax.pdf (Last accessed: 24.11.2020).

20. The $90 \%$ economy that lockdowns will leave behind. URL: https://www.economist.com/briefing/2020/04/30/the-90economy-that-lockdowns-will-leave-behind (Last accessed: 28.11.2020).

21. Taylor, A. Why vaccine nationalism is winning. Washington Post. 02.09.2020. URL: https://www.washingtonpost.com/ world/2020/09/03/why-coronavirus-vaccine-nationalism-is-winning/ (Last accessed: 15.11.2020).

22. Pfizer and BioNTech announce vaccine candidate against covid-19 achieved success in first interim analysis from phase 3 study. URL: https://www.pfizer.com/news/press-release/press-release-detail/pfizer-and-biontech-announce-vaccinecandidate-against (Last accessed: 28.11.2020).

23. These are the countries that have pre-ordered the most COVID vaccines. URL: https://www.weforum.org/agenda/2020/11/countries-vaccines-covid-coronavirus-pandemic-moderna-pfizer-astrazeneca-covax-who?utm_sour$c e=$ twitter\&utm_medium $=$ social_scheduler\&utm_term $=$ COVID-19\&utm_content $=27 / 11 / 2020+14: 00$ (Last accessed: 28.11.2020).

24. Astra-Oxford Shot Is Key to Escaping Pandemic for Many Nations. URL: https://www.bloomberg.com/news/articles/2020-11-23/astra-delivers-but-can-t-match-rivals-here-s-what-we-know (Last accessed: 24.11.2020).

25. COVID-19 Vaccine Prices Revealed From Pfizer, Moderna, and AstraZeneca. URL: https://observer.com/2020/11/ covid19-vaccine-price-pfizer-moderna-astrazeneca-oxford (Last accessed: 24.11.2020).

26. Herd immunity. Episode No. 1. Science in 5. WHO's conversations in science. WHO. URL: https://www.who.int/emergencies/diseases/novel-coronavirus-2019/media-resources/science-in-5/episode-1(Last accessed: 24.11.2020).

27. Weintraub, R., Subramanian, L.Covid-19 vaccine to vaccination: why leaders must invest in delivery strategies now. URL: https://www.healthaffairs.org/doi/10.1377/hlthaff.2020.01523 (Last accessed: 20.11.2020).

28. Schoch-Spana, M., Brunson, E. The Public's Role in COVID-19 Vaccination: Planning Recommendations Informed by Design Thinking and the Social, Behavioral, and Communication Sciences. URL: https://www.centerforhealthsecurity. org/our-work/publications/the-publics-role-in-covid-19-vaccination (Last accessed: 14.11.2020).

29. Seeber, L., Michl, B. A design thinking approach to effective vaccine safety communication. URL: https://pubmed.ncbi. nlm.nih.gov/25859673/ (Last accessed: 14.11.2020).

30. WHO SAGE values framework for the allocation and prioritization of COVID-19 vaccination. URL: https://apps. who.int/iris/bitstream/handle/10665/334299/WHO-2019-nCoV-SAGE_Framework-Allocation_and_prioritization2020.1-eng.pdf?sequence=1\&isAllowed $=y$ (Last accessed: 25.10 .2020 ).

31. Trump Administration Acts to Ensure Coverage of Life-Saving COVID-19 Vaccines \& Therapeutics. URL: https:// www.cms.gov/newsroom/press-releases/trump-administration-acts-ensure-coverage-life-saving-covid-19-vaccinesthera peutics (Last accessed: 14.11.2020).

32. Health Insurance Coverage: Early Release of Estimates From the National Health Interview Survey. 2019 URL: https:// www.cdc.gov/nchs/data/nhis/earlyrelease/insur202009-508.pdf (Last accessed: 14.11.2020).

33. How Much Will A Covid-19 Vaccine Cost? URL: https://www.forbes.com/sites/katiejennings/2020/11/17/howmuch-will-a-covid-19-vaccine-cost/?sh=58cfddb7576d (Last accessed: 17.11.2020).

34. Hughes, G. Air Cargo Media Presentation. IATA. URL: https://www.iata.org/contentassets/6b115abfb8314f9c963577 b94c360f91/cargo-media-briefing.pdf (Last accessed: 27.11.2020).

35. As race to develop a COVID-19 vaccine nears the finish line, airlines prepare for 'mission of the century'. URL: https:// nationalpost.com/news/world/as-race-to-develop-a-covid-19-vaccine-nears-the-finish-line-airlines-prepare-formission-of-the-century (Last accessed: 30.11.2020).

36. Vaccine: Frankfurt Airport prepares for logistical challenge of a lifetime. URL: https://www.euronews.com/2020/11/28/ vaccine-frankfurt-airport-prepares-for-logistical-challenge-of-a-lifetime (Last accessed: 28.11.2020).

37. Про Державний бюджет України на 2021 рік: Проєкт Закону України. 2020. URL: https:/w1.c1.rada.gov.ua/pls/ zweb2/webproc4_1?pf3511=69938 [in Ukrainian] (Last accessed: 14.11.2020).

38. Бюджетний запит на 2021-2023 роки. Міністерство охорони здоров’я України. Індивідуальний. Форма 2021-2 . URL: https://moz.gov.ua/uploads/5/26563-231_2021_2.pdf [in Ukrainian] (Last accessed: 14.11.2020).

39. COVID-19 Explorer. Ukraine. World Health Organization 2020. URL: https://worldhealthorg.shinyapps.io/covid/ (Last accessed: 28.11.2020).

40. Guidance on developing a national deployment and vaccination plan for COVID-19 vaccines. Interim guidance. 16.11.2020. World Health Organization 2020. URL: https://apps.who.int/iris/rest/bitstreams/1315396/retrieve (Last accessed:16.11.2020). 
41. Moderna to charge \$25-\$37 for COVID-19 vaccine: CEO tells paper. Reuters. 22.11.2020 URL: https://www.reuters. com/article/us-health-coronavirus-moderna-eu-idUSKBN2810W4 (Last accessed: 22.11.2020).

42. The cost of one dose of the Sputnik V vaccine will be less than $\$ 10$ for international markets. URL: https://sputnikvaccine. $\mathrm{com} /$ newsroom/pressreleases/the-cost-of-one-dose-will-be-less-than-10-for-international-markets/ (Last accessed: 25.11.2020).

43. Comparing COVID-19 Vaccines: Timelines, Types and Prices. URL: https://www.biospace.com/article/comparing-covid-19-vaccines-pfizer-biontech-moderna-astrazeneca-oxford-j-and-j-russia-s-sputnik-v/ (Last accessed: 28.11.2020).

44. Johnson \& Johnson Announces Agreement with U.S. Government for 100 Million Doses of Investigational COVID-19 Vaccine. URL: https://www.jnj.com/johnson-johnson-announces-agreement-with-u-s-government-for-100-million-doses-of-investigational-covid-19-vaccine (Last accessed: 28.11.2020).

45. J\&J starts two-dose trial of its COVID-19 vaccine candidate. URL: https://www.reuters.com/article/us-health-coronavirus-j-j-britain/jj-starts-two-dose-trial-of-its-covid-19-vaccine-candidate-idUSKBN27W00P (Last accessed: 28.11.2020).

46. COVID-19 Vaccine Prices Revealed From Pfizer, Moderna, and AstraZeneca. URL: https://observer.com/2020/11/ covid19-vaccine-price-pfizer-moderna-astrazeneca-oxford (Last accessed: 05.12.2020).

47. Sinovac coronavirus vaccine offered by Chinese city for emergency use costs $\$ 60$. URL: https://www.reuters.com/ article/us-health-coronavirus-china-vaccine-idUSKBN2710UQ (Last accessed: 28.11.2020).

48. Coronavirus: Chinese vaccine giant quotes higher price for doses. South China Morning Post. URL: https://www.scmp. com/news/china/science/article/3098032/coronavirus-chinese-vaccine-giant-quotes-higher-price-doses (Last accessed: 28.11.2020).

49. Roadmap for prioritizing population groups for vaccines against COVID-19 An Approach to Inform Planning and Subsequent Recommendations Based Upon Epidemiologic Setting and Vaccine Supply Scenarios. World Health Organization 2020. URL: https://www.who.int/immunization/sage/meetings/2020/october/Session03_Roadmap_Prioritization_Covid-19_vaccine.pdf (Last accessed: 28.11.2020).

50. Employed population by type of economic activity in 2012-2019. (2020). State Statistics Service of Ukraine. URL: http://www.ukrstat.gov.ua/operativ/operativ2014/rp/zn_ed/zn_ed_u/zn_ed_2013_u.htm [in Ukrainian] (Last accessed: 28.11.2020).

51. Distribution of the permanent population by sex, separate age groups and type of locality (2020). State Statistics Service of Ukraine. URL: http://database.ukrcensus.gov.ua/MULT/Dialog/statfile_c.asp [in Ukrainian] (Last accessed: 28.11.2020).

52. Guidance on estimating the cost of introducing new vaccines into the national immunization system. World Health Organization. 2002. URL: https://apps.who.int/iris/bitstream/handle/10665/112613/WHO_V-B_02.11_rus.pdf?sequence=1\&isAllowed=y [in Russian] (Last accessed: 28.11.2020).

53. Economics of immunization: a guide to the literature and other resources. URL: https://apps.who.int/iris/bitstream/ handle/10665/68526/WHO_V-B_04.02_eng.pdf?sequence=1\&isAllowed=y (Last accessed: 28.11.2020).https://apps. who.int/iris/bitstream/handle/10665/68526/WHO_V-B_04.02_eng.pdf;sequence $=1$

54. Guidance on developing a national deployment and vaccination plan for COVID-19 vaccines. Interim guidance. World Health Organization 2020. URL: https://apps.who.int/iris/rest/bitstreams/1315396/retrieve (Last accessed: 16.11.2020

Received 10.12.20

Revised 17.12.20

Accepted 17.12.20

\section{В.М. Геєиь, І.О. Луніна, О.В. Степанова}

Державна установа «Інститут економіки та прогнозування НАН України», вул. Панаса Мирного, 26, Київ, 01011, Україна,

+380 44280 1234, gvm@ief.org.ua

\section{ФОРМУВАННЯ ФІСКАЛЬНОГО ПРОСТОРУ НА ШЛЯХУ ПОДОЛАННЯ ВАКЦИННОГО НАЦІОНАЛІЗМУ ТА ЗАБЕЗПЕЧЕННЯ СТІЙКОСТІ РОЗВИТКУ}

Вступ. Пандемія COVID-19 спричинила розгортання найбільшої за останні десятиріччя глобальної економічної та суспільної кризи. В цих умовах світова спільнота розробляє та приймає заходи, спрямовані на подолання пандемії, одним з яких має стати швидка вакцинація населення безпрецедентних масштабів. 
Проблематика. В умовах інтенсивної циркуляції коронавірусної інфекції вакцинація може її призупинити та стати чинником поступового економічного відновлення.

Мета. Аналіз передумов та особливостей розвитку фіскального простору для забезпечення вакцинації проти COVID-19 в Україні як одного з найбільш вагомих чинників економічного відновлення в новітніх умовах становлення глобального ринку вакцин.

Матеріали й методи. Порівняльний аналіз та теоретичне узагальнення процесів та тенденцій сучасного становлення глобального ринку вакцин проти COVID-19, висвітлених в сучасних наукових та практичних публікаціях, а також аналіз офіційної статистики та аналітичних матеріалів Державної служби статистики України, Організації Об’єднаних Націй, Всесвітньої організації охорони здоров’я.

Результати. Визначено сучасні тенденції розвитку глобального ринку вакцин проти COVID-19, що містять ознаки гострої конкуренції в умовах недостатності виробничих потужностей та дефіциту вакцин. Обгрунтовано наявність протиріч між процесами набуття вакциною проти COVID-19 статусу глобального суспільного блага та вакцинним націоналізмом. Здійснено оцінювання потреб у розширенні фіскального простору України з метою успішного проведення вакцинації населення проти COVID-19 за альтернативними сценаріями - з урахуванням пріоритетності охоплення різних груп населення.

Висновки. Формування фіскального простору для вакцинації населення проти COVID-19 є одним із центральних елементів боротьби з COVID-19, що дозволить провести поступову поетапну профілактичну імунізацію населення та перервати ланцюг заражень, що дозволить швидше перейти до економічного відновлення.

Ключові слова: пандемія COVID-19, вакцинація, глобальне суспільне благо, вакцинний націоналізм, фіскальний простір, економічне відновлення. 